American Journal of Economics and Business Administration 2 (4): 384-394, 2010

ISSN 1945-5488

(C) 2010 Science Publications

\title{
New Technologies in the Payment System Industries: The SEPA Project
}

\author{
${ }^{1}$ Armando Calabrese, ${ }^{2}$ Massimo Gastaldi, ${ }^{1}$ Irene Iacovelli and ${ }^{1}$ Nathan Levialdi Ghiron \\ ${ }^{1}$ Department of Business Engineering, Tor Vergata University of Rome, \\ Viale del Politecnico 1, 00133 Rome, Italy \\ ${ }^{2}$ Department of Electrical and Information Engineering, University of "L'Aquila", \\ Monteluco di Roio, 67100 L'Aquila, Italy
}

\begin{abstract}
Problem statement: The Single Euro Payments Area (SEPA) project plans to establish an integrated market for extending European integration to retail payments; it aims to provide incentives for using payment systems instead of cash for all micro payments, in order to improve both efficiency and competition in the Euro area. In this study we described the SEPA and its effects on competition and innovation in the payment systems. Moreover, we will discuss the main technological innovations (particularly mobile payments, biometrics payments and smart cards) and their impacts on retail payments. Approach: In order to analyze the impact of new technologies on cash usage we employed a mathematical model. This model is an extension of duopolistic competition to three market players; it allows analyzing market changes caused both by SEPA and technological innovations. Results: Our numerical simulations showed that new technologies cause a reduction of cash usage, such as SEPA project states. Conclusion: New payment technologies provided new benefits than the traditional payment systems. These new technologies reduced the transaction times and the logistic costs of cash management; moreover they improve the transactions safety, their easiness and convenience. Such benefits push consumers to use these new payment technologies for micro-payments (pubs and bars, nightclubs, fast food outlets, retail fuel, convenience store and vending machines), thus reducing the use of cash such as SEPA project states.
\end{abstract}

Key words: Two-sided markets, payment system, technological innovation, SEPA project

\section{INTRODUCTION}

From 2002 cash stocks have been constantly increasing. At the end of 2007, the number of circulating banknotes was 12.1 billion and their value was 676.6 billion Euros; these data, compared to the data of late 2006, show an increase of $6.7 \%$ in volume and $7.7 \%$ in value. About coins, their number, at the end of 2007, was 75.8 billion and their value was 19.2 billion Euros, with an increase respectively of $9.1 \%$ and 7.6\% compared to the levels of 2006 (European Central Bank, 2007). The withdrawal rate of banknotes (authenticated and checked in order to verify their validity for payments) from circulation is substantially steady (about 3\%). In 2007, about 5.5 billion cash have been considered as not appropriate for circulation and have been replaced; these data, compared to the data of 2006, show an increase of $5.1 \%$ and a rate of invalidity of $17.0 \%$ (16.9\% in 2006). Cash produced annually has to be sufficient in order to enable transactions increase, to manage cash replacement rate and to provide cash stocks of the National Central Banks in each European member state. Such cash stocks represent a buffer in order to deal with possible variations in cash demand; they are necessary for substituting void cash, for dealing with demand peaks and for optimizing the cash transportation among the several National Central Banks in the Euro area (www.ecb.int).

The above data show that cash management represents a problem for governments, companies and citizens in the European countries and involve both human and financial costs. In Italy, for example, cash management costs around 10 billion Euros a year, 2/3 of which burden on enterprises, while the other $1 / 3$ on the banking sector; these costs have to be added to costs afforded annually by Public Administrations.

The costs of cash management and cash lack of safety (due to loss and theft) is a limitation for commercial transactions. The preference in using cash can be explained considering both the lack of awareness

Corresponding Author: Armando Calabrese, Department of Business Engineering, Tor Vergata University of Rome, Viale del Politecnico 1, 00133 Rome, Italy 
about the costs of its use and to the perception that new technological system are too expensive and insecure, especially for micro-payment transactions. In Italy, according to Italian Banks Association data (2004), cash is used for $90 \%$ of overall payments.

Since cash transactions represent a source of inefficiency for overall market, the SEPA project aims to reduce its use for making payments. The SEPA represents an important European assignment in order to fully exploit, Euro benefits for retail payments and to make a unified payment market, integrating 31 nations by 2010 . Thus, the SEPA plans to extend the European integration process to retail payments, using payment systems other than cash (credit cards, bank transfer and receipts), in order to improve efficiency and competition in the Euro area.

Since the SEPA aims to make payment systems more efficient it provides incentives for improving quality in payment networks and for developing innovative solutions. The expected outcome of the SEPA will be the development of new market opportunities for both traditional credit card operators and new entrants. Actually, in current payment systems market, due to new technologies (i.e., chips for cell phones and biometric systems), new players, such as large distribution networks and telecommunication operators may compete effectively in this industry (Sarlak and Hastiani, 2008).

The technological development in payment systems such as mobile payments, biometrics payments and smart cards, represents a chance both for increasing the number of payment devices and for improving the market efficiency (through queues reductions, payment security enhancement, interoperability among different payment networks and reduction of logistic costs of cash management). In order to reach the goal of an integrated market of retail payment it will be important to persuade customers about quality and reliability of new services and to develop the use of devices which are already widespread such as cell phones (Sattar and AL-Fayoumi, 2007; Bozinis, 2007; Sadek et al., 2010).

This study analyses the main innovations in payment systems and, employing some numerical simulations, will show that benefits introduced by new technologies provide incentives for their use such as the SEPA project aims.

The study is organized as follows: in the introduction we define a two-sided market, highlighting the main literature contributions and the main differences of our study with respect to existing researches. Then, we describe the SEPA project and illustrate the main technological development in the payment system industry. In material and method we describe our model while in results we show numerical simulation findings. In discussion, we focus on the impact of logistic and technological benefits provided by new payment systems on the cash usage and finally, we conclude the study with some observations and comments.

Literature review: Payment system services are regarded as Two-Sided Markets (Armstrong, 2006; Calabrese et al., 2006; Doganoglu and Wright, 2005; Rochet and Tirole, 2004a; 2004b; Roson, 2005; Schiff, 2003). More generically, the multi-sided platform markets can be defined as industries characterized by the interconnection between different groups of customers through a platform and by a combined pricing strategies for each side (Evans, 2003; Calabrese et al., 2008a; 2008b; Rochet and Tirole, 2004a; 2004b). These industries range from computer games, to information technologies, to media, to telecommunication industries, to payment systems. According to the above definition a platform allows to increase the social surplus only if are observed three necessary and sufficient conditions: distinct groups of users, having their demand coordinated with each other, by mean of a platform that coordinate their trade more efficiently than bilateral relationships (Evans, 2003; Rochet and Tirole, 2004a; 2004b). In an industrial economics framework the multi-sided platform industries are related to the concepts of network externalities and of multi-product pricing (Rochet and Tirole, 2004a; 2004b).

Therefore, the payment system is characterized by the interaction of two different customers' categories: consumers and merchants. The interaction between these categories of users is influenced by the presence of indirect network-effects: the benefit for consumers of joining a platform depends on the number of merchants accepting that payment system and the benefit of joining a platform for merchants is related to number of consumers using that platform (Evans, 2003). Thus the opposite network size represents a quality parameter in the platform selection (Roson, 2005) and since each network size depends on its price, the utility for a payment system user depends on both market prices (Roson, 2005). Furthermore, such an interaction between the two market sides of a platform depends on their strategic choices (Wright, 2003a; 2003b).

Many authors have studied the competition among payment systems (Farrell, 2006; Rochet and Tirole, 2002; 2003). In particular, Chakravorti and Roson (2006) analyze competition among payment networks and market equilibrium: oligopolistic competition, 
cartels, symmetric and asymmetric networks. Their results show how competition increases both consumer and merchant welfare.

The relationship between technological innovation and platform competition has received little attention in scientific literature (Distaso et al., 2006; Milne, 2005; Zou, 2006). Calabrese et al. (2008a) analyzed the role that technology innovation has in the competitiveness and efficiency of the payment system industry. They showed that payment platforms can develop product/service innovations or price differentiations in order to deal with market competition effectively.

This study differs from the existing literature in several ways. Firstly, in our research we will describe the Single Euro Payments Area (SEPA) project and its effects on competition and innovation for payment systems. Then, we will explain the main technological innovations for retail payments and their effects on competition in payment systems. Finally, we will use the model proposed in our previous study (Calabrese et al., 2008a) in order to shows how benefits improvements, due to new technologies, cause both increase of consumers usage of new payment technologies and a reduction of cash usage, such as SEPA project states.

The Single Euro Payments Area (SEPA): The SEPA project has been planned and carried out by European Commission (EC), European Central Bank (ECB) and European Payments Council (EPC).The European Commission has been responsible for political leadership and normative frameworks (payment services directive). The European Central Bank has been involved with guidelines and controls of the SEPA processes and it is responsible of its roadmap. The European Payments Council, which is a self regulation body founded in 2002 on the initiative of European Banks, is responsible for decisions and coordination policies about the SEPA.

The SEPA project involves 31 European countries:

- 16 European Union countries which utilize Euro as national currency (Austria, Belgium, France, Finland, Germany, Greece, Ireland, Italy, Luxembourg, Netherlands, Portugal, Slovenia, Spain, Cyprus and Malta Slovakia)

- 11 European Union countries which use a national currency different from Euro but make payments in Euro (Bulgaria, Denmark, Estonia, Latvia, Lithuania, Poland, Czech Republic, United Kingdom, Romania, Sweden, Hungary)

- Iceland, Liechtenstein, Norway and Switzerland

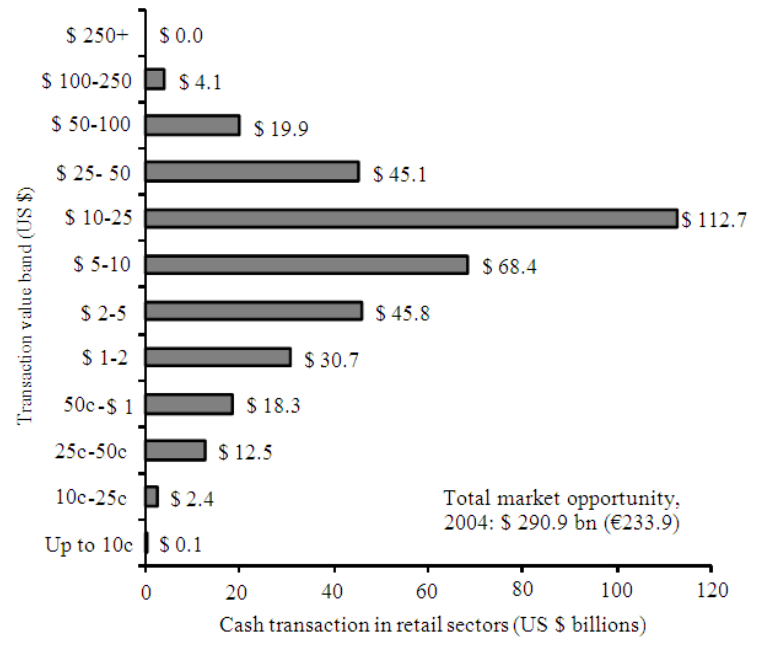

Fig. 1: Cash transaction in Europe 2004 (Source: Datamonitor, 2006)

The SEPA aims to establish a coordinated payment system in which European citizens may make or receive payments by credit cards, bank transfer and receipts, using only the same bank account in all Euro area; its goal is to provide an efficient, secure, easy and costeffective payment system (European Central Bank, 2006). Thus, the SEPA allows payment systems to exploit scale economies and efficiency improvements; it is expected to improve competition among payment system and to stimulate innovation and new services development (European Central Bank, 2006). Moreover, such increased competition is expected to reduce both costs of banking services and cross-border transactions costs.

In Europe, cash usage involves high logistic costs such as currencies transport costs, security costs, insurance costs and for banks, currencies management costs too. In Europe, 360 billion transactions a year are made by cash and $80 \%$ of these are less than 25 Euros each (Fig. 1). The data presented in Fig. 1 refers to the values of cash payments in the main retail sectors such as pubs and bars, nightclubs, fast food outlets, retail fuel, convenience store and vending machines for 20 European countries (Austria, Belgium, Czech Republic, Denmark, Finland, France, Germany, Greece, Hungary, Ireland, Italy, Netherlands, Norway, Poland, Portugal, Spain, Sweden, Switzerland, Turkey and UK). Moreover, the main European countries using cash as primarily payment system for transaction under $25 \$$ are: United Kingdom, Germany and Italy respectively with US\$ 58.7 billion, 51.2 and US\$ 33.4 billion (Datamonitor, 2006).

For example, in Italy customer's preferences in using cash are due to distrust toward alternative 
payment systems and to unclear understanding of their transaction benefits; the costs of cash management are not perceived since they are not clearly charged on banking customers. Moreover, other factors, such as commerce fragmentation, tax evasion, hidden work and concerns of fraud (i.e., credit card), contribute to cash preference.

Thus, since cash continues to be widely used for micro-payments (Fig. 1) and logistic costs of its management and transportation are high, it is necessary to induce customers to use alternative payment systems in order to increase transactions efficiency.

The switch from cash to alternative payment system could be caused leveraging both information and pricing policies. In particular, pricing of payment services should be related with their real operating costs, in order to align customers' choices to the most cost-effective system. At present, banks according to the SEPA project are involved in promoting infrastructures improvement of credit cards (chip) and in adopting new international standards.

The use, of more efficient and technology intensive payment systems, is stimulated by the Directive 2007/64/CE on payment services (Payment Services Directive-PSD). This Directive regulates the offer of retail payment services in the EU; it represents the legal basis of the SEPA. The PSD aims to encourage the use of efficient and reliable non-cash payment systems. The PSD in addition to credit cards, bank transfer and receipts (SEPA) also apply to electronic money and to payments through telecommunications networks or digital devices (European Central Bank, 2007).

The PSD will allow non-bank players (the so called Payment Institutions) to provide payment services, stimulating competition in payment sector; moreover it sets minimum quality requirements payment systems will have to provide. Thus, the SEPA is expected to increase competition in retail payment system market, to reduce prices for customers, to innovate services and to improve their quality.

The payment systems industry: Over the last few years, payment systems have been characterized by several technological innovations, by a growing competition and also by new market players (telecom operators). In particular, the innovation of information and telecommunication technologies has made possible the development of new tools and new payment services.

At present, the most used payment system, other than cash, is creditldebt card. Nowadays, new technologies are emerging such as contact and contactless smart cards, mobile and biometric payments. In the following, these technologies and their impacts on the market will be analyzed.
The latest generation of payment cards (debit and credit) is smart cards, plastic devices provided with an integrated microchip in order to manage more data and more services than the magnetic strip.

The contactless payment system is based on a RFID (Radio Frequency Identification) technology (a data microchip and an antenna) allowing data transmission via radio frequency using a RFID reader (http://gartner.com).

Currently, financial circuits such as Visa, MasterCard and American Express are marketing new smart cards-more safety, speed and flexibility-over traditional chip cards (www.cartedipagamento.com). These new systems use a dual interface chip card EMV (Europay MasterCard Visa), which allows making payments both contact and contactless. In particular, if the payment is below a certain amount it is possible to pay simply bringing the card to a POS (Point Of Sale) without using any type of PIN (Personal Identification Number) or receipt signature. Instead, for higher payments it is possible to pay only in a chip and PIN mode. When a transaction is carried out in an on-line mode, the contactless off-line counter will restore the available credit limit.

The mobile payments are allowed by NFC (Near Field Communication) technology, which is a communication technology for short-range wireless connections; it allows devices in close contact to exchange data. NFC technology, developed jointly by Sony and Philips, is an evolution of RFID and interconnection technologies.

A mobile NFC phone is composed by a Central Processing Unit (CPU), an antenna, an NFC chip and a secure element. M-payments use also (SMS) Short Message Service, bluetooth and internet access as means for making payments. An Italian Banks Association Research (January 2008) estimates that by 2012 there will be 303 million NFC phones in the world, around $21 \%$ of all mobile phones that will be marketed in that year.

For example, in Japan NFC technology is provided by NTT DoCoMo (www.nttdocomo.com), the Japanese mobile operator, through the Sony FeliCa chip; it enables to make payments simply bringing the phone to a reader; it identifies the telephone smart card and charges the cost of a product or service on a bank account or on a credit card associated with a prepaid SIM phone. Belgium mobile operators introduced a payment service using GSM mobile phones. This service is developed by Banksys and uses text messages and secret code in order to enabling payments; the transaction occurred is communicated to users by sending a message. In Italy, a mobile virtual operator 
Poste Mobile allows bank transfers, sending telegrams, to check bank flows and other services using a mobile phone (http://www.postemobile.it). Poste Mobile is going to introduce micro-payments and to purchase tickets of mobility services (as taxi, bus and train). Based on the same technology several banking groups are going to enter the m-payment market.

The biometric system allows making payments through the scanning and measurement of somebody characteristics, such as the finger imprint and, through algorithms, comparing them with a database. For example, Pay by Touch (www.paybytouch.com) has created a biometric payment system based on fingerprint recognition. The mechanism used is rather simple: at the checkout of a shop the consumer places his/her finger on a scanner which memorizes fingerprint and sends the information to a data processing centre. The recorded fingerprint is then compared to the one registered in a database, which was taken when the customer signed up for the service. After a buyer has been recognized by a central database, he/she has to enter a secret code number and he/she will immediately be charged on his/her bank account. In order to utilize such a system, merchants are required to install new terminals.

\section{MATERIALS AND METHODS}

We analyze the impact of such new technologies on cash usage through a model described in our previous research (Calabrese et al., 2008a). This model is an extension of Chakravorti and Roson (2006) model of duopolistic competition to three players (smart cards, M-payments and biometric payments); it allows employing an analysis of market transformation due both to SEPA and technological innovations. The main technologies we consider are M-payments and biometric payment, competing with the incumbent (smart cards) and cash.

In the following, we report the main assumptions made in Calabrese et al. (2008a):

- Let us assume platform 1, represents the incumbent, i.e., smart cards; platforms 2 and 3 represent the new entrants, m-payments and biometric payments respectively. The fourth system, which is not a technological platform at all, is cash. The latter is available to all consumers and merchants and does not require any additional fees; we suppose no utility is obtained by either consumers or merchants in using cash

- All consumers adopt a single payment system (single homing)
- The total benefit that each consumer obtains by utilizing the platform $\mathrm{i}=1,2,3$ is given by multiplying the transaction benefit, $\mathrm{h}_{\mathrm{i}}{ }^{\mathrm{c}}$, by the number of merchants, $\mathrm{D}_{\mathrm{i}}{ }^{\mathrm{m}}$. The benefits, $\mathrm{h}_{\mathrm{i}}{ }^{\mathrm{c}}$, are distributed according a uniform distribution in $[0$, $\tau_{\mathrm{i}}$, where $\tau_{\mathrm{i}}$ represents the maximum benefit that a consumer may obtain from platform $i$ and is calculated by adding different attributes (results section)

- $\quad$ Each consumer pays the platform an annual fee, $\mathrm{f}_{\mathrm{i}}^{\mathrm{c}}$

- The consumer utility $\mathrm{U}^{\mathrm{c}}$ (in using one of the three platforms) is calculated from the difference between total transaction benefits and fees. Moreover let us assume that once a consumer becomes a member of a platform, he will use this payment system exclusively; thus the utility for the representative consumer $\mathrm{U}^{\mathrm{c}}$ can be expressed as:

$$
\mathrm{U}^{\mathrm{c}}=\max \left\{\begin{array}{l}
0,\left(\mathrm{~h}_{1}{ }^{\mathrm{c}} \mathrm{D}_{1}{ }^{\mathrm{m}}-\mathrm{f}_{1}^{\mathrm{c}}\right),\left(\mathrm{h}_{2}{ }^{\mathrm{c}} \mathrm{D}_{2}{ }^{\mathrm{m}}-\mathrm{f}_{2}{ }^{\mathrm{c}}\right), \\
\left(\mathrm{h}_{3}{ }^{\mathrm{c}} \mathrm{D}_{3}{ }^{\mathrm{m}}-\mathrm{f}_{3}{ }^{\mathrm{c}}\right)
\end{array}\right\}
$$

- $\quad$ Each merchant sells only one product and is multihoming; he pays each platform he uses a transaction fee, $\mathrm{f}_{\mathrm{i}}^{\mathrm{m}}$

- The transaction benefit, $\mathrm{h}_{\mathrm{i}}{ }^{\mathrm{m}}$, which each merchant obtains from platform $\mathrm{i}$, is distributed according a uniform distribution in $\left[0, \mu_{\mathrm{i}}\right]$, where $\mu_{\mathrm{i}}$ represents the maximum merchant benefit. $\mu_{\mathrm{i}}$ is calculated by adding different attributes (results section)

- The merchant utility $\mathrm{U}^{\mathrm{m}}$, in using platform $\mathrm{i}$, is calculated from the difference between benefits and fees. A merchant will use a payment system if he obtains positive benefit from it; thus the utility for the representative merchant $\mathrm{U}^{\mathrm{m}}$ can be expressed as:

$$
\begin{aligned}
& \mathrm{U}^{\mathrm{m}}=\max \left\{0,\left(\mathrm{~h}_{1}{ }^{\mathrm{m}}-\mathrm{f}_{1}{ }^{\mathrm{m}}\right) \mathrm{D}_{1}{ }^{\mathrm{c}}\right\} \\
& +\max \left\{0,\left(\mathrm{~h}_{2}{ }^{\mathrm{m}}-\mathrm{f}_{2}{ }^{\mathrm{m}}\right) \mathrm{D}_{2}{ }^{\mathrm{c}}\right\}+\max \left\{0,\left(\mathrm{~h}_{3}{ }^{\mathrm{m}}-\mathrm{f}_{3}{ }^{\mathrm{m}}\right) \mathrm{D}_{3}{ }^{\mathrm{c}}\right\}
\end{aligned}
$$

where, $D_{i}^{c}$ represents the number of consumers using the payment system offered by platform $i$.

A consumer utilizes an alternative payment system to cash, if such a system meets two requirements: It produces a positive utility and the consumer utility $\left(\mathrm{U}^{\mathrm{c}}\right)$-from the payment system chosen-is greater than any other payment system.

In Calabrese et al. (2008a), we use the same assumptions as the Chakravorti and Roson (2006) model, but expand upon them in order to encompass competition among three platforms. The market share 
can be seen in Fig. 2, where each consumer is represented by a point whose coordinates $\left(\mathrm{h}_{1}{ }^{\mathrm{c}} \mathrm{D}_{1}{ }^{\mathrm{m}}, \mathrm{h}_{2}{ }^{\mathrm{c}}\right.$ $\mathrm{D}_{2}{ }^{\mathrm{m}}, \mathrm{h}_{3}{ }^{\mathrm{c}} \mathrm{D}_{3}{ }^{\mathrm{m}}$ ) express the total benefits of using platforms 1,2 or 3 (each point is obtained by multiplying the three transaction benefits $h_{i}{ }^{c}$ by the number of merchants who accept the payment system $\mathrm{i}$, $\left.\mathrm{D}_{\mathrm{i}}^{\mathrm{m}}\right)$.

In Fig. 2, the parallelepiped is divided into 8 sections. Each one is derived from intersection of the parallelepiped with the three planes that are obtained according to the values assumed by $\mathrm{f}_{\mathrm{i}}^{\mathrm{c}}$.

Consumers within section 1 use cash, since the net benefits offered by the three platforms are negative. In sections 5, 2 and 4 consumers choose the system which offers them positive utility-the smart cards, the mpayment and the biometric payment, respectively.

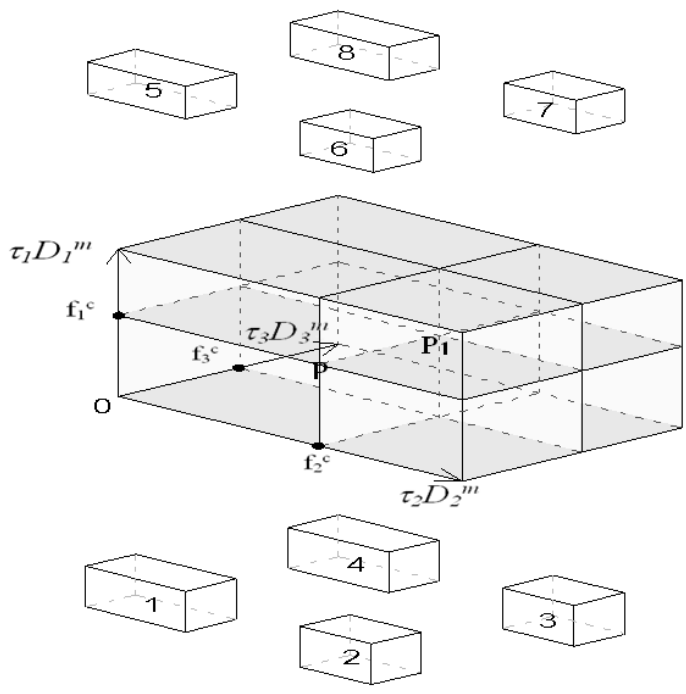

Fig. 2: Consumer market shares on platform i (Calabrese et al., 2008a)

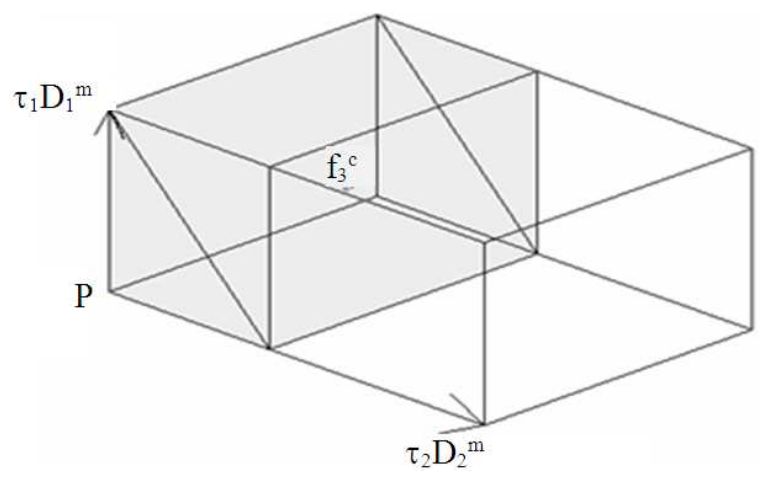

Fig. 3: Enlargement of section 6 of the parallelepiped in Fig. 2 (Calabrese et al., 2008a)
In sections 6,8 and 3 the competition is only between the two platforms that offer a positive net benefit.

In Fig. 3, we show section 6 of parallel-piped (Fig. 2) where, in this particular case, the competition is between platform 1 (the smart cards) and 2 (the Mpayment). In fact in section 6 since $\mathrm{h}_{1}{ }^{\mathrm{c}} \mathrm{D}_{1}{ }^{\mathrm{m}}>\mathrm{f}_{1}{ }^{\mathrm{c}}$ and $\mathrm{h}_{2}{ }^{\mathrm{c}} \mathrm{D}_{2}{ }^{\mathrm{m}}>\mathrm{f}_{2}{ }^{\mathrm{c}}$, the smart cards (platform 1) and the Mpayment (platform 2) offer positive net benefits; while given that $\mathrm{h}_{3}{ }^{\mathrm{c}} \mathrm{D}_{3}{ }^{\mathrm{m}}<\mathrm{f}_{3}{ }^{\mathrm{c}}$, the biometric payment (platform 3 ) offers a negative net benefit to customer.

Figure 3 shows a volume divided into two parts. The grey section represents the percentage of demand equally divided between two platforms. In fact, if platforms offer consumers the same value of net benefits (grey volume of Fig. 3), consumers choose on the basis of relative utility and the border between the two market shares is given by a 45 degree plane that splits the grey volume into two sections (Chakravorti and Roson, 2006). The white volume represents the additional percentage of demand to be added to the platform which offers the greatest net benefit to the consumer. "Only the network offering the highest consumer surplus $\left(\tau \mathrm{D}^{\mathrm{m}}-\mathrm{f}^{\mathrm{c}}\right)$ attracts consumers" in the white volume (Chakravorti and Roson, 2006); for example if $\left(\tau_{2} D_{2}{ }^{m}-f_{2}{ }^{c}\right)>\left(\tau_{1} D_{1}{ }^{m}-f_{1}{ }^{c}\right)$ the consumer utility is the greatest using platform 2 .

Section 7 represents the only volume in which consumers obtain positive utility in using all three platforms. The market share of each platform is represented in Fig. 4.

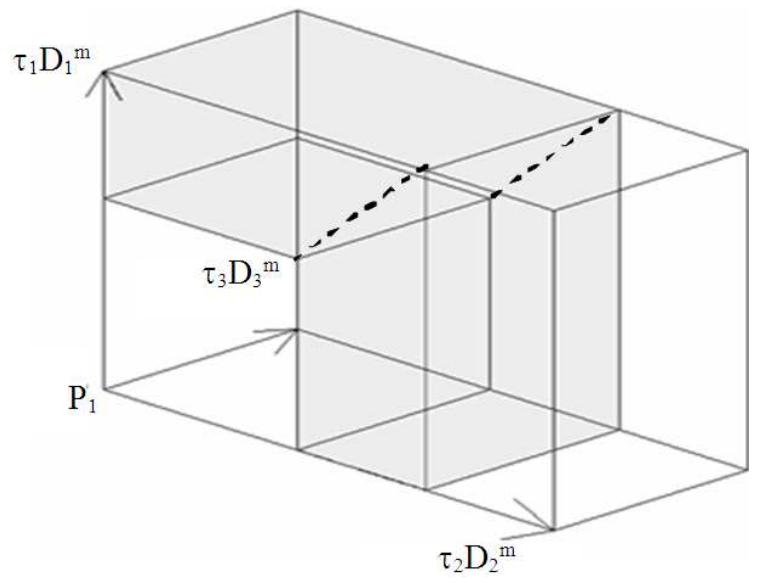

Fig. 4: Enlargement of section 7 of the parallelepiped in Fig. 2 (Calabrese et al., 2008a) 
In order to obtain the grey volume in Fig. 4 we found the intermediate value among $\tau_{1} \mathrm{D}_{1}{ }^{\mathrm{m}}-\mathrm{f}_{1}{ }^{\mathrm{c}}, \tau_{2} \mathrm{D}_{2}{ }^{\mathrm{m}}$ $\mathrm{f}_{2}{ }^{\mathrm{c}}$ and $\tau_{3} \mathrm{D}_{3}{ }^{\mathrm{m}}-\mathrm{f}_{3}{ }^{\mathrm{c}}$. The two platforms that offer the greatest net benefits gain the half of grey volume to sum to their respective market shares.

The white cube at the bottom left of Fig. 4 is obtained by the third power of the minimum among $\tau_{1} D_{1}{ }^{m}-f_{1}{ }^{c}, \tau_{2} D_{2}{ }^{m}-f_{2}{ }^{c}$ and $\tau_{3} D_{3}{ }^{m}-f_{3}{ }^{c}$, that is the utility of the payment system which provides the minimum net benefit among all platforms. Since each platform provides a positive utility, each platform gains $1 / 3$ of the white cube.

In order to obtain the white parallelepiped at the right of Fig. 4 we calculated the maximum among $\tau_{1} \mathrm{D}_{1}{ }^{\mathrm{m}}-\mathrm{f}_{1}{ }^{\mathrm{c}}, \tau_{2} \mathrm{D}_{2}{ }^{\mathrm{m}}-\mathrm{f}_{2}^{\mathrm{c}}$ and $\tau_{3} \mathrm{D}_{3}{ }^{\mathrm{m}}-\mathrm{f}_{3}{ }^{\mathrm{c}}$; then we calculated the volume of this parallelepiped. Only the platform that provides the maximum value of net benefit gains the additional market share represented by this parallelepiped.

The market shares of consumer demand, for each platform, is obtained by adding the volumes (2-8) in Fig. 2, divided by the total market demand $\left(\mathrm{m}_{1} * \mathrm{~m}_{2} *\right.$ $\left.\mathrm{m}_{3}\right)$.

The total customer demand for each platform is represented respectively by the following Eq. 3:

$$
\begin{aligned}
\mathrm{D}_{1}{ }^{\mathrm{c}}= & \left\{\left\{\left[\mathrm{b}_{1} * \mathrm{f}_{2}{ }^{\mathrm{c}} * \mathrm{f}_{3}{ }^{\mathrm{c}}\right]+\left[\left(\left(\min \left(\mathrm{b}_{1}, \mathrm{~b}_{2}\right)\right)^{2} * \mathrm{f}_{3}{ }^{\mathrm{c}} \frac{1}{2}\right)+\left(\mathrm{b}_{1}-\right.\right.\right.\right. \\
& \left.\left.\left(\min \left(\mathrm{b}_{1}, \mathrm{~b}_{2}\right)\right)\right) *\left(\left(\min \left(\mathrm{b}_{1}, \mathrm{~b}_{2}\right)\right) * \mathrm{f}_{3}{ }^{\mathrm{c}}\right)\right]+\left[\left(\left(\min \left(\mathrm{b}_{1}, \mathrm{~b}_{3}\right)\right)^{2} *\right.\right. \\
& \left.\left.\mathrm{f}_{2}{ }^{\mathrm{c}} \frac{1}{2}+\left(\mathrm{b}_{1}-\left(\min \left(\mathrm{b}_{1}, \mathrm{~b}_{3}\right)\right)\right) *\left(\min \left(\mathrm{b}_{1}, \mathrm{~b}_{3}\right)\right) * \mathrm{f}_{2}{ }^{\mathrm{c}}\right]+\mathrm{Z}_{\mathrm{i}}\right\} \\
& \left./ \mathrm{m}_{1} * \mathrm{~m}_{2} * \mathrm{~m}_{3}\right\} * \mathrm{C} \\
\mathrm{D}_{2}{ }^{\mathrm{c}}= & \left\{\left\{\left[\mathrm{b}_{2} * \mathrm{f}_{1}^{\mathrm{c} *} * \mathrm{f}_{3}{ }^{\mathrm{c}}\right]+\left[\left(\left(\min \left(\mathrm{b}_{1}, \mathrm{~b}_{2}\right)\right)^{2} * \mathrm{f}_{3}{ }^{\mathrm{c}} \frac{1}{2}\right)+\left(\mathrm{b}_{2}-\right.\right.\right.\right. \\
& \left.\left.\left(\min \left(\mathrm{b}_{1}, \mathrm{~b}_{2}\right)\right)\right) *\left(\left(\min \left(\mathrm{b}_{1}, \mathrm{~b}_{2}\right)\right) * \mathrm{f}_{3}{ }^{\mathrm{c}}\right)\right]+\left[\left(\left(\min \left(\mathrm{b}_{2}, \mathrm{~b}_{3}\right)\right)^{2} *\right.\right. \\
& \left.\left.\mathrm{f}_{1}^{\mathrm{c}} \frac{1}{2}+\left(\mathrm{b}_{2}-\left(\min \left(\mathrm{b}_{2}, \mathrm{~b}_{3}\right)\right)\right) *\left(\min \left(\mathrm{b}_{2}, \mathrm{~b}_{3}\right)\right) * \mathrm{f}_{1}{ }^{\mathrm{c}}\right]+\mathrm{Z}_{\mathrm{i}}\right\} \\
& \left./ \mathrm{m}_{1} * \mathrm{~m}_{2} * \mathrm{~m}_{3}\right\} * \mathrm{C} \\
\mathrm{D}_{3}{ }^{\mathrm{c}}= & \left\{\left\{\left[\mathrm{b}_{3} * \mathrm{f}_{1}{ }^{\mathrm{c}} * \mathrm{f}_{2}{ }^{\mathrm{c}}\right]+\left[\left(\left(\min \left(\mathrm{b}_{1}, \mathrm{~b}_{3}\right)\right)^{2} * \mathrm{f}_{2}{ }^{c} \frac{1}{2}\right)+\left(\mathrm{b}_{3}-\right.\right.\right.\right. \\
& \left.\left.\left(\mathrm{min}\left(\mathrm{b}_{1}, \mathrm{~b}_{3}\right)\right)\right) *\left(\left(\min \left(\mathrm{b}_{1}, \mathrm{~b}_{3}\right)\right) * \mathrm{f}_{2}{ }^{\mathrm{c}}\right)\right]+\left[\left(\left(\min \left(\mathrm{b}_{2}, \mathrm{~b}_{3}\right)\right)^{2} *\right.\right. \\
& \left.\left.\mathrm{f}_{1}^{\mathrm{c}} \frac{1}{2}+\left(\mathrm{b}_{3}-\left(\min \left(\mathrm{b}_{2}, \mathrm{~b}_{3}\right)\right)\right) *\left(\min \left(\mathrm{b}_{2}, \mathrm{~b}_{3}\right)\right) * \mathrm{f}_{1}{ }^{\mathrm{c}}\right]+\mathrm{Z}_{\mathrm{i}}\right\} \\
& \left./ \mathrm{m}_{1} * \mathrm{~m}_{2} * \mathrm{~m}_{3}\right\} * \mathrm{C}
\end{aligned}
$$

Where:

$$
\begin{aligned}
& \mathrm{m}_{\mathrm{i}}=\tau_{\mathrm{i}^{*}} \mathrm{D}_{\mathrm{i}}^{\mathrm{m}} \mathrm{i}=1,2,3 \\
& \mathrm{~b}_{\mathrm{i}}=\mathrm{m}_{\mathrm{i}} \mathrm{f}_{\mathrm{i}}^{\mathrm{c}} \mathrm{i}=1,2,3 \\
& \mathrm{C}=\text { Total number of consumers } \\
& \mathrm{B}=\operatorname{Min}\left\{\mathrm{b}_{1}, \mathrm{~b}_{2}, \mathrm{~b}_{3}\right\} \\
& \mathrm{A}=\operatorname{Max}\left\{\mathrm{b}_{1}, \mathrm{~b}_{2}, \mathrm{~b}_{3}\right\} \\
& \mathrm{M}=\operatorname{Max}\left\{\min \left\{\mathrm{b}_{1}, \mathrm{~b}_{2}\right\} ; \min \left\{\mathrm{b}_{1}, \mathrm{~b}_{3}\right\} ; \min \left\{\mathrm{b}_{2}, \mathrm{~b}_{3}\right\}\right\}
\end{aligned}
$$

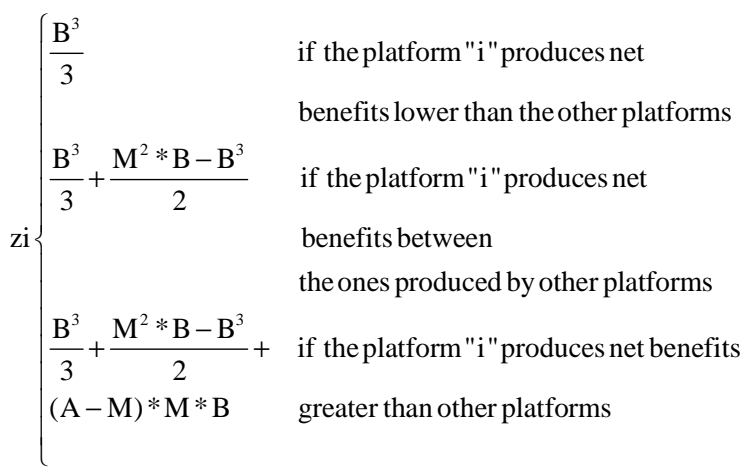

$\mathrm{B}^{3}$ represents the white cube in the left of parallelepiped in Fig. 4: according to Eq. 3 for each platform, $1 / 3 * \mathrm{~B}^{3}$ has to be added to market shares. $\mathrm{M}^{2} * \mathrm{~B}-\mathrm{B}^{3}$ represents the grey area in Fig. 4: according to Eq. 3 for two platforms that offer the greatest net benefits, $1 / 2 *\left(M^{2} * B-B^{3}\right)$ has to be added to $1 / 3 * B^{3}$. $(A-M) * M * B$ represents the white volume in the right part of parallelepiped of Fig. 4: according to Eq. 3 for the platform that provide maximum net benefits $(\mathrm{A}-\mathrm{M}) * \mathrm{M} * \mathrm{~B}$ has to be added to $1 / 3 * \mathrm{~B}^{3}+1 / 2 *\left(\mathrm{M}^{2} * \mathrm{~B}-\mathrm{B}^{3}\right)$.

Under the assumption that the merchants accept the payment system $\mathrm{i}$ if and only if the benefits are greater than the costs $\left(\mathrm{h}_{\mathrm{i}}^{\mathrm{m}} \geq \mathrm{f}_{\mathrm{i}}^{\mathrm{m}}\right)$, the demand of the merchants is equal to:

$\mathrm{D}_{\mathrm{i}}^{\mathrm{m}}=\operatorname{Pr}\left(\mathrm{h}_{\mathrm{i}}{ }^{\mathrm{m}} \mathrm{f}_{\mathrm{i}}^{\mathrm{m}}\right) * \mathrm{M}=\left(1-\mathrm{K}_{\mathrm{i}}^{\mathrm{m}}\left(\mathrm{f}_{\mathrm{i}}^{\mathrm{m}}\right)\right) * \mathrm{M}$

where, $\mathrm{M}$ represents the number of merchants on the market.

For simplicity let us assume that the merchants benefits are distributed with a uniform distribution, $\mathrm{K}_{\mathrm{i}}^{\mathrm{m}}$, in $\left[0, \mu_{\mathrm{i}}\right]$.

Each platform faces two types of costs: the annual cost, $\mathrm{g}_{\mathrm{i}}$, for serving a consumer and a transaction cost, $\mathrm{c}_{\mathrm{i}}$, for serving a merchant.

The profit of each platform is given by:

$\pi_{\mathrm{I}}=\left(\mathrm{f}_{\mathrm{i}}^{\mathrm{c}}-\mathrm{g}_{\mathrm{i}}\right) \mathrm{D}_{\mathrm{i}}^{\mathrm{c}}+\left(\mathrm{f}_{\mathrm{i}}^{\mathrm{m}}-\mathrm{c}_{\mathrm{i}}\right) \mathrm{D}_{\mathrm{i}}^{\mathrm{m}} \mathrm{D}_{\mathrm{i}}^{\mathrm{c}}$

The platforms choose the fees of consumers and merchants simultaneously and not cooperatively in order to maximize their profits.

Although, our model differs from Chakravorti and Roson (2006), we obtain similar results.

The fees that maximize profits are determined by a modified Lerner's index:

$\mathrm{p}^{\mathrm{c}}+\mathrm{f}^{\mathrm{m}}-\mathrm{c}=\left(\mathrm{p}^{\mathrm{c}} / \varepsilon^{\mathrm{c}}\right)=\mathrm{f}^{\mathrm{m}} /\left(\varepsilon^{\mathrm{m}}+\varepsilon^{\mathrm{cm}}-\varepsilon^{\mathrm{m}} \varepsilon^{\mathrm{c}}\right)$ 
where, $p^{c}=\left(f^{c}-g\right) / D^{m}$ "is the per-transaction revenue minus cost from serving a consumer" (Chakravorti and Roson, 2006).

For simplicity, let us assume that both elasticity of the consumer's demand, $\varepsilon^{c}$ and elasticity of the merchant's demand, $\varepsilon^{\mathrm{m}}$, are for the consumer, $\varepsilon^{\mathrm{c}}=1 / \tau$ and for the merchant, $\varepsilon^{\mathrm{m}}=1 / \mu$. So, if the benefit $\tau$ for the consumer and the benefit $\mu$ for the merchant increase, each market side is not particularly sensitive to price variations. As regards the elasticity, $\varepsilon^{\mathrm{cm}}$ (variation of the consumers' demand with respect to a variation of the merchants' fee) let us suppose that it is directly proportional to $1 / \mu$, multiplied by a constant $\lambda$ (Calabrese et al., 2008a). In fact the lower the platform sets merchant fees, the more the merchant demand increases and indirectly the more the consumer demand increases.

\section{RESULTS}

Consumers and merchants show some opposition towards adopting and accepting innovative payment systems alternative to cash. In this study we assume that any innovation in a payment system will be more easily adopted if potential consumers and merchants perceive it as being advantageous in terms of benefits provided. In the following we refer to logistic and technological benefit or to consumers and merchants benefits indifferently.

In order to collect our data for numerical simulations, we employed some interviews to experts on such technologies and industries. Firstly, we identified consumer and merchant attributes on which depend their incentives to adopt new payment system and secondly, we defined the consumer's benefit, $\tau$ and the merchant's benefit, $\mu$.

Therefore, on the consumers' side the drivers on which depend adoption of new payment systems are: learning costs; safety; speed (according to Datamonitor (2006), a consumer obtains greater benefit by contactless payment than traditional payment systems ("a contactless payment made at an offline terminal will take no more than 500 milliseconds to be verified, compared to several seconds for a standard card transaction"..."One of the big problems with the use of cards for low value payments is the time it takes. But contactless is faster than cash in these circumstances as you don't have to wait for change")); interoperability; reduction of transaction times; easiness of use; multipurpose; convenience of using. Instead, on the merchants' side the attributes that determine their incentives to adopt new payment systems are: reduction of logistic costs of cash management; safety; speed; interoperability; reduction of transaction time; easiness of use; convenience of using; multipurpose.

In this study in order to calculate the maximum consumer's benefit, $\tau$ and the maximum merchant's benefit, $\mu$, we gave, for each platform, a value between 0 and 0.5 to each attribute listed above. The values $\tau$ and $\mu$ are the sum of each attribute, thus they can have a value between 0 and 4 . For example, it is possible to assume that the lower the learning costs of a payment system, the more its diffusion will be; the greater the transaction safety and speed of a payment system, the more its diffusion will be; moreover the interoperability of a payment system facilitates its use in the markets.

In the results, we analyse the competition between cash, smart cards, biometric and cell phone systems. Through some numerical simulations whose input data have been tested through interviews with experts on such technologies and industries. We assumed as starting values [4] for smart cards, [2.6] for m-payments and [2.1] for biometric payments. According to our panel of experts, in the current market situations, smart cards are the most used technology, followed by mpayments and biometric payments, thus the chosen value $[4,2.6,2.1]$ means to represent such situation numerically.

Our simulation inputs are: $\tau, \mu$ (Table 1) and merchant fees (determined as a mark-up). Our simulation outputs are customer fees, market shares and platform profits.

We assumed that top management of both biometric and mobile payment platforms can choose between two opposing options: proactive and reactive strategies. The proactive strategy consists of an improvement in logistic and technological benefits both on the consumers' side, $\tau$ and on the merchants' side, $\mu$. Moreover when top management of platform i decide to be proactive, it increases both $\tau$ and $\mu$ with respect to the data in Table 1 . The reactive strategy does not involve any investment in logistic and technological benefits and consequentially does not generate any change in benefit level compared to Table 1 .

\begin{tabular}{llll}
\multicolumn{4}{l}{ Table 1: A proxy of Italian market situation } \\
\hline Input and output & Smart cards & M-payments & Biometric payments \\
\hline$\tau$ & 4.00 & 2.60 & 2.10 \\
$\mu$ & 4.00 & 2.60 & 2.10 \\
$\mathrm{f}^{\mathrm{m}}$ & 1.70 & 1.20 & 1.20 \\
$\mathrm{f}^{\mathrm{c}}$ & 2.13 & 1.46 & 1.39 \\
$\mathrm{D}^{\mathrm{m}}$ & 0.58 & 0.54 & 0.43 \\
$\mathrm{D}^{\mathrm{c}}$ & 0.07 & 0.00 & 0.00 \\
$\pi$ & 0.05 & 0.00 & 0.00 \\
\hline
\end{tabular}


Am. J. of Economics and Business Administration 2 (4): 384-394, 2010

Top management of a smart card platform can choose between two options, proactive and reactive strategies. The proactive strategy is the same of Table 1 (smart cards are characterized by the greatest benefits) and it consists in lowering merchants' fees. The smart cards reactive strategy does not involve any investment in technologies with regard to current situation and does not generate any change in benefit levels compared to Table 1.

We assumed that platforms choose their strategies simultaneously and not cooperatively and that each platform has a consumer demand as defined by equation (3). The demand of each payment system depends both on net benefit of the system itself and on net benefit generated by the competitors (Calabrese et al., 2008a).

The Table 2-9, show the results of numerical simulations according to both the above assumption and the model described. In each table, the current market situation is showed in the white columns of each table, while the simulated scenarios are showed as the bold columns.

Table 2: Smart Cards (SC) and M-Payment (MP) management choose a proactive strategy, Biometric Payment (BP) management a reactive strategy

\begin{tabular}{lllllll}
\hline Input and output & SC & MP & BP & SC & MP & BP \\
\hline $\boldsymbol{\tau}$ & $\mathbf{4 . 0 0}$ & $\mathbf{2 . 6 0}$ & $\mathbf{2 . 1 0}$ & $\mathbf{4 . 0 0}$ & $\mathbf{3 . 6 0}$ & $\mathbf{2 . 1 0}$ \\
$\boldsymbol{\mu}$ & $\mathbf{4 . 0 0}$ & $\mathbf{2 . 6 0}$ & $\mathbf{2 . 1 0}$ & $\mathbf{4 . 0 0}$ & $\mathbf{3 . 6 0}$ & $\mathbf{2 . 1 0}$ \\
$\mathrm{f}^{\mathrm{m}}$ & 1.70 & 1.20 & 1.20 & $\mathbf{1 . 6 0}$ & $\mathbf{1 . 4 0}$ & $\mathbf{1 . 1 0}$ \\
$\mathrm{f}^{\mathrm{c}}$ & 2.13 & 1.46 & 1.39 & $\mathbf{2 . 1 2}$ & $\mathbf{1 . 5 6}$ & $\mathbf{1 . 3 9}$ \\
$\mathrm{D}^{\mathrm{m}}$ & 0.58 & 0.54 & 0.43 & $\mathbf{0 . 6 0}$ & $\mathbf{0 . 6 1}$ & $\mathbf{0 . 4 7}$ \\
$\mathrm{D}^{\mathrm{c}}$ & 0.07 & 0.00 & 0.00 & $\mathbf{0 . 0 9}$ & $\mathbf{0 . 2 8}$ & $\mathbf{0 . 0 0}$ \\
$\boldsymbol{\pi}$ & 0.05 & 0.00 & 0.00 & $\mathbf{0 . 0 6}$ & $\mathbf{0 . 2 3}$ & $\mathbf{0 . 0 0}$ \\
\hline
\end{tabular}

Table 3: All three payment system management (Smart Cards (SC), M-Payment (MP) and Biometric Payment (BP))

\begin{tabular}{lllllll}
\hline Input and output & SC & MP & BP & SC & MP & BP \\
\hline $\boldsymbol{\tau}$ & $\mathbf{4 . 0 0}$ & $\mathbf{2 . 6 0}$ & $\mathbf{2 . 1 0}$ & $\mathbf{4 . 0 0}$ & $\mathbf{3 . 6 0}$ & $\mathbf{3 . 1 0}$ \\
$\boldsymbol{\mu}$ & $\mathbf{4 . 0 0}$ & $\mathbf{2 . 6 0}$ & $\mathbf{2 . 1 0}$ & $\mathbf{4 . 0 0}$ & $\mathbf{3 . 6 0}$ & $\mathbf{3 . 1 0}$ \\
$\mathrm{f}^{\mathrm{m}}$ & 1.70 & 1.20 & 1.20 & $\mathbf{1 . 6}$ & $\mathbf{1 . 4 0}$ & $\mathbf{1 . 4 0}$ \\
$\mathrm{f}^{\mathrm{c}}$ & 2.13 & 1.46 & 1.39 & $\mathbf{2 . 1 2}$ & $\mathbf{1 . 5 6}$ & $\mathbf{1 . 5 2}$ \\
$\mathrm{D}^{\mathrm{m}}$ & 0.58 & 0.54 & 0.43 & $\mathbf{0 . 6 0}$ & $\mathbf{0 . 6 1}$ & $\mathbf{0 . 5 5}$ \\
$\mathrm{D}^{\mathrm{c}}$ & 0.07 & 0.00 & 0.00 & $\mathbf{0 . 0 9}$ & $\mathbf{0 . 2 8}$ & $\mathbf{0 . 0 7}$ \\
$\boldsymbol{\pi}$ & 0.05 & 0.00 & 0.00 & $\mathbf{0 . 0 6}$ & $\mathbf{0 . 2 3}$ & $\mathbf{0 . 0 5}$ \\
\hline
\end{tabular}

Table 4: Smart Card (SC) management choose a proactive strategy, both M-Payments (MP) and Biometric Payments (BP) management reactive

\begin{tabular}{lllllll}
\hline Input and output & SC & MP & BP & SC & MP & BP \\
\hline $\boldsymbol{\tau}$ & $\mathbf{4 . 0 0}$ & $\mathbf{2 . 6 0}$ & $\mathbf{2 . 1 0}$ & $\mathbf{4 . 0 0}$ & $\mathbf{2 . 6 0}$ & $\mathbf{2 . 1 0}$ \\
$\boldsymbol{\mu}$ & $\mathbf{4 . 0 0}$ & $\mathbf{2 . 6 0}$ & $\mathbf{2 . 1 0}$ & $\mathbf{4 . 0 0}$ & $\mathbf{2 . 6 0}$ & $\mathbf{2 . 1 0}$ \\
$\mathrm{f}^{\mathrm{m}}$ & 1.70 & 1.20 & 1.20 & $\mathbf{1 . 6 0}$ & $\mathbf{1 . 1 0}$ & $\mathbf{1 . 1 0}$ \\
$\mathrm{f}^{\mathrm{c}}$ & 2.13 & 1.46 & 1.39 & $\mathbf{2 . 1 2}$ & $\mathbf{1 . 4 5}$ & $\mathbf{1 . 3 9}$ \\
$\mathrm{D}^{\mathrm{m}}$ & 0.58 & 0.54 & 0.43 & $\mathbf{0 . 6 0}$ & $\mathbf{0 . 5 8}$ & $\mathbf{0 . 4 8}$ \\
$\mathrm{D}^{\mathrm{c}}$ & 0.07 & 0.00 & 0.00 & $\mathbf{0 . 1 2}$ & $\mathbf{0 . 0 3}$ & $\mathbf{0 . 0 0}$ \\
$\pi$ & 0.05 & 0.00 & 0.00 & $\mathbf{0 . 0 8}$ & $\mathbf{0 . 0 2}$ & $\mathbf{0 . 0 0}$ \\
\hline
\end{tabular}

Table 5: Smart Cards (SC) and Biometric Payments (BP) management choose proactive strategy, M-Payments (MP) management reactive

\begin{tabular}{lllllll}
\hline Input and output & SC & MP & BP & SC & MP & BP \\
\hline $\boldsymbol{\tau}$ & $\mathbf{4 . 0 0}$ & $\mathbf{2 . 6 0}$ & $\mathbf{2 . 1 0}$ & $\mathbf{4 . 0 0}$ & $\mathbf{2 . 6 0}$ & $\mathbf{3 . 0 1}$ \\
$\boldsymbol{\mu}$ & $\mathbf{4 . 0 0}$ & $\mathbf{2 . 6 0}$ & $\mathbf{2 . 1 0}$ & $\mathbf{4 . 0 0}$ & $\mathbf{2 . 6 0}$ & $\mathbf{3 . 1 0}$ \\
$\mathrm{f}^{\mathrm{m}}$ & 1.70 & 1.20 & 1.20 & $\mathbf{1 . 6 0}$ & $\mathbf{1 . 1 0}$ & $\mathbf{1 . 4 0}$ \\
$\mathrm{f}^{\mathrm{c}}$ & 2.13 & 1.46 & 1.39 & $\mathbf{2 . 1 2}$ & $\mathbf{1 . 4 5}$ & $\mathbf{1 . 5 2}$ \\
$\mathrm{D}^{\mathrm{m}}$ & 0.58 & 0.54 & 0.43 & $\mathbf{0 . 6 0}$ & $\mathbf{0 . 5 8}$ & $\mathbf{0 . 5 5}$ \\
$\mathrm{D}^{\mathrm{c}}$ & 0.07 & 0.00 & 0.00 & $\mathbf{0 . 1 1}$ & $\mathbf{0 . 0 3}$ & $\mathbf{0 . 0 9}$ \\
$\pi$ & 0.05 & 0.00 & 0.00 & $\mathbf{0 . 0 8}$ & $\mathbf{0 . 0 2}$ & $\mathbf{0 . 0 7}$ \\
\hline
\end{tabular}

Table 6: All three payment system managements choose a reactive strategy (Smart Cards (SC), M-Payment (MP) and Biometric Payment (BP))

\begin{tabular}{lllllll}
\hline Input and output & SC & MP & BP & SC & MP & BP \\
\hline $\boldsymbol{\tau}$ & $\mathbf{4 . 0 0}$ & $\mathbf{2 . 6 0}$ & $\mathbf{2 . 1 0}$ & $\mathbf{4 . 0 0}$ & $\mathbf{2 . 6 0}$ & $\mathbf{2 . 1 0}$ \\
$\boldsymbol{\mu}$ & $\mathbf{4 . 0 0}$ & $\mathbf{2 . 6 0}$ & $\mathbf{2 . 1 0}$ & $\mathbf{4 . 0 0}$ & $\mathbf{2 . 6 0}$ & $\mathbf{2 . 1 0}$ \\
$\mathrm{f}^{\mathrm{m}}$ & 1.7 & 1.20 & 1.20 & $\mathbf{1 . 7 0}$ & $\mathbf{1 . 1 0}$ & $\mathbf{1 . 1 0}$ \\
$\mathrm{f}^{\mathrm{c}}$ & 2.13 & 1.46 & 1.39 & $\mathbf{2 . 1 3}$ & $\mathbf{1 . 4 5}$ & $\mathbf{1 . 3 9}$ \\
$\mathrm{D}^{\mathrm{m}}$ & 0.58 & 0.54 & 0.43 & $\mathbf{0 . 5 8}$ & $\mathbf{0 . 5 8}$ & $\mathbf{0 . 4 8}$ \\
$\mathrm{D}^{\mathrm{c}}$ & 0.07 & 0.00 & 0.00 & $\mathbf{0 . 0 7}$ & $\mathbf{0 . 0 3}$ & $\mathbf{0 . 0 0}$ \\
$\pi$ & 0.05 & 0.00 & 0.00 & $\mathbf{0 . 0 6}$ & $\mathbf{0 . 0 2}$ & $\mathbf{0 . 0 0}$ \\
\hline
\end{tabular}

Table 7: Both M-Payments (MP) and Biometric Payments (BP) management choose a proactive strategy, Smart Cards (SC) management reactive

\begin{tabular}{lllllll}
\hline Input and output & SC & MP & BP & SC & MP & BP \\
\hline $\boldsymbol{\tau}$ & $\mathbf{4 . 0 0}$ & $\mathbf{2 . 6 0}$ & $\mathbf{2 . 1 0}$ & $\mathbf{4 . 0 0}$ & $\mathbf{3 . 6 0}$ & $\mathbf{3 . 1 0}$ \\
$\boldsymbol{\mu}$ & $\mathbf{4 . 0 0}$ & $\mathbf{2 . 6 0}$ & $\mathbf{2 . 1 0}$ & $\mathbf{4 . 0 0}$ & $\mathbf{3 . 6 0}$ & $\mathbf{3 . 1 0}$ \\
$\mathrm{f}^{\mathrm{m}}$ & 1.70 & 1.20 & 1.20 & $\mathbf{1 . 7 0}$ & $\mathbf{1 . 4 0}$ & $\mathbf{1 . 4 0}$ \\
$\mathrm{f}^{\mathrm{c}}$ & 2.13 & 1.46 & 1.39 & $\mathbf{2 . 1 3}$ & $\mathbf{1 . 5 6}$ & $\mathbf{1 . 5 2}$ \\
$\mathrm{D}^{\mathrm{m}}$ & 0.58 & 0.54 & 0.43 & $\mathbf{0 . 5 8}$ & $\mathbf{0 . 6 1}$ & $\mathbf{0 . 5 5}$ \\
$\mathrm{D}^{\mathrm{c}}$ & 0.07 & 0.00 & 0.00 & $\mathbf{0 . 0 5}$ & $\mathbf{0 . 2 8}$ & $\mathbf{0 . 0 8}$ \\
$\pi$ & 0.05 & 0.00 & 0.00 & $\mathbf{0 . 0 4}$ & $\mathbf{0 . 2 3}$ & $\mathbf{0 . 0 6}$ \\
\hline
\end{tabular}

Table 8: Both Smart Cards (SC) and Biometric Payments (BP) management choose a reactive strategy, M-Payments (MP) management proactive

\begin{tabular}{lllllll}
\hline Input and output & SC & MP & BP & SC & MP & BP \\
\hline $\boldsymbol{\tau}$ & $\mathbf{4 . 0 0}$ & $\mathbf{2 . 6 0}$ & $\mathbf{2 . 1 0}$ & $\mathbf{4 . 0 0}$ & $\mathbf{3 . 6 0}$ & $\mathbf{2 . 1 0}$ \\
$\boldsymbol{\mu}$ & $\mathbf{4 . 0 0}$ & $\mathbf{2 . 6 0}$ & $\mathbf{2 . 1 0}$ & $\mathbf{4 . 0 0}$ & $\mathbf{3 . 6 0}$ & $\mathbf{2 . 1 0}$ \\
$\mathrm{f}^{\mathrm{m}}$ & 1.70 & 1.20 & 1.20 & $\mathbf{1 . 7 0}$ & $\mathbf{1 . 4 0}$ & $\mathbf{1 . 1 0}$ \\
$\mathrm{f}^{\mathrm{c}}$ & 2.13 & 1.46 & 1.39 & $\mathbf{2 . 1 3}$ & $\mathbf{1 . 5 6}$ & $\mathbf{1 . 3 9}$ \\
$\mathrm{D}^{\mathrm{m}}$ & 0.58 & 0.54 & 0.43 & $\mathbf{0 . 5 8}$ & $\mathbf{0 . 6 1}$ & $\mathbf{0 . 4 8}$ \\
$\mathrm{D}^{\mathrm{c}}$ & 0.07 & 0.00 & 0.00 & $\mathbf{0 . 0 6}$ & $\mathbf{0 . 2 9}$ & $\mathbf{0 . 0 0}$ \\
$\boldsymbol{\pi}$ & 0.05 & 0.00 & 0.00 & $\mathbf{0 . 0 4}$ & $\mathbf{0 . 2 3}$ & $\mathbf{0 . 0 0}$ \\
\hline
\end{tabular}

Table 9: Both Smart Cards (SC) and M-Payments (MP) management choose a reactive strategy, Biometric Payments (BP) management proactive

\begin{tabular}{lllllll}
\hline Input and output & SC & MP & BP & SC & MP & BP \\
\hline $\boldsymbol{\tau}$ & $\mathbf{4 . 0 0}$ & $\mathbf{2 . 6 0}$ & $\mathbf{2 . 1 0}$ & $\mathbf{4 . 0 0}$ & $\mathbf{2 . 6 0}$ & $\mathbf{3 . 1 0}$ \\
$\boldsymbol{\mu}$ & $\mathbf{4 . 0 0}$ & $\mathbf{2 . 6 0}$ & $\mathbf{2 . 1 0}$ & $\mathbf{4 . 0 0}$ & $\mathbf{2 . 6 0}$ & $\mathbf{3 . 1 0}$ \\
$\mathrm{f}^{\mathrm{m}}$ & 1.70 & 1.20 & 1.20 & $\mathbf{1 . 7 0}$ & $\mathbf{1 . 1 0}$ & $\mathbf{1 . 4 0}$ \\
$\mathrm{f}^{\mathrm{c}}$ & 2.13 & 1.46 & 1.39 & $\mathbf{2 . 1 3}$ & $\mathbf{1 . 4 5}$ & $\mathbf{1 . 5 2}$ \\
$\mathrm{D}^{\mathrm{m}}$ & 0.58 & 0.54 & 0.43 & $\mathbf{0 . 5 8}$ & $\mathbf{0 . 5 8}$ & $\mathbf{0 . 5 5}$ \\
$\mathrm{D}^{\mathrm{c}}$ & 0.07 & 0.00 & 0.00 & $\mathbf{0 . 0 7}$ & $\mathbf{0 . 0 3}$ & $\mathbf{0 . 1 0}$ \\
$\pi$ & 0.05 & 0.00 & 0.00 & $\mathbf{0 . 0 5}$ & $\mathbf{0 . 0 2}$ & $\mathbf{0 . 0 8}$ \\
\hline
\end{tabular}


Am. J. of Economics and Business Administration 2 (4): 384-394, 2010

\section{DISCUSSION}

The first column in Table 10 (P stands for proactive strategy and $\mathrm{R}$ stands for reactive strategy-as we have defined in results section) represents different strategic combinations $(\mathrm{i}, \mathrm{j}, \mathrm{y})$ : i represents the top management strategy of a smart card platform, $j$ the top management strategy of m-payments and finally $y$ the top management strategy of biometric payments. The second, third and fourth columns present the consumers demand; its depends on both consumers' benefits and merchants' benefits of payment systems (i,j,y). Finally in the last column there is the cash demand; it depends on both consumers' benefits and merchants' benefits of payment systems (i,j,y) (Fig. 2).

According the above results, we have eight different competitive scenarios. Table 10 represents the comparison among customers' demand (in bold; these values are from Table 1) and customers' demand that we obtained by simulations employed for each strategic combinations (in white).

The present situation line shows that the most used payment systems are both cash and smart cards; the first one is used by $93 \%$ while the second one by $7 \%$ of consumers (Table 1). These simulations are consistent with the data of Italian market. Moreover, the simulation results (results and Table 10) show how the logistic and technological benefits of smart cards, mpayments and biometric payments impact on market demand of cash. The market demand of cash is minimum when smart cards, m-payments and biometric payments provide simultaneously high logistic and technological benefits (that is, all three platform management adopt a proactive strategy); in fact the simulation results show that cash demand shift from a value of $93 \%$ (a proxy of the present Italian situation) to a value of $56 \%$. Instead, when smart cards, m-payments and biometric payments simultaneously provide low logistic and technological benefits (that is, all three platform management adopt a reactive strategy), the cash demand is equal to $90 \%$.

Table 10: Consumers' demands in different competitive scenarios obtained combining strategic choice of each payment system i

\begin{tabular}{lllll}
\hline Strategic combinations & SC & MP & BP & Cash \\
\hline Present situation & $\mathbf{0 . 0 7}$ & $\mathbf{0 . 0 0}$ & $\mathbf{0 . 0 0}$ & $\mathbf{0 . 9 3}$ \\
(P;P;P) & 0.09 & 0.28 & 0.07 & 0.56 \\
(P;P;R) & 0.09 & 0.28 & 0.00 & 0.63 \\
(P;R;P) & 0.11 & 0.03 & 0.09 & 0.77 \\
(P;R;R) & 0.12 & 0.03 & 0.00 & 0.85 \\
(R;R;R) & 0.07 & 0.03 & 0.00 & 0.90 \\
(R;P;P) & 0.05 & 0.28 & 0.08 & 0.59 \\
(R;R;P) & 0.07 & 0.03 & 0.10 & 0.80 \\
(R;P;R) & 0.06 & 0.29 & 0.00 & 0.65 \\
\hline
\end{tabular}

\section{CONCLUSION}

New payment technologies (smart cards, mpayments and biometric payments) provide new benefits than the traditional payment systems (cash and magnetic cards). These new technologies reduce the transaction times and the logistic costs of cash management; moreover they improve the transactions safety, their easiness and convenience of using. Such benefits encourage consumers to employ these new payment technologies for micro-payments (pubs and bars, nightclubs, fast food outlets, retail fuel, convenience store and vending machines), thus reducing the use of cash such as SEPA project states.

These results are consistent with an explorative study on the factors that affect consumer adoption of new payment systems (Mallat, 2007). Our findings show that the consumers' preference towards new payment systems depends on some benefits (learning costs; safety; speed; interoperability; reduction of transaction times; easiness of use; convenience of using; multipurpose), selected according to experts interviews on such technologies (results section).

Particularly, according to our results (Table 10) the more the benefits provided by new payment technologies the more will be their substitution effect with cash.

The factors on which depends the adoption of new payment systems are slightly different from the ones described from Mallat (2007). The differences can be explained considering that it refers exclusively to $\mathrm{m}$ payments while in this study we consider also smart cards and biometric payments. Moreover, in this study a simulation analysis provides some strategic scenarios about the SEPA impacts on cash reduction for retail payments while the qualitative approach of focus groups interviews of the explorative study (Mallat, 2007) was aimed to discover the factors on which depend the incentives in using m-payments.

\section{REFERENCES}

Armstrong, M., 2006. Competition in two-sided markets. RAND J. Econ., 37: 668-691. DOI: 10.1111/j.1756-2171.2006.tb00037.x

Bozinis, I.A., 2007. International economic relations and Information Communication Technologies (ICT) use: Economic globalization via economic digitalization. Am. J. Applied Sci., 4: 188-191. http://www.scipub.org/fulltext/ajas/ajas44188191.pdf 
Calabrese, A., M. Gastaldi and N.L. Ghiron, 2006. Mobile Networks Prospects: The Multi-Sided Platform Approach in the Competition Analysis. In: The Economics of Online Markets and ICT Networks, Cooper, R., G. Madden, A. Lloyd and M. Schipp (Eds.). Physica-Verlag HD, Heidelberg, Germany, ISBN: 10: 3790817066, pp: 92-110.

Calabrese, A., M. Gastaldi I. Iacovelli and N.L. Ghiron, 2008a. Innovation and competition in the two-sided markets: The case of the payment system. Int. J. Manage. Network Econ., 1: 1-20. DOI: 10.1504/ijmne.2008.018677

Calabrese, A., M. Gastaldi I. Iacovelli and N.L. Ghiron, 2008b. Ultra Broadband Competition in Two-Sided Markets. In: Special Issue on "Communications and Strategies, Aravantinos, E., J.S. Bedo, B.G. Choi, E. Noam and A. Vallee, (Eds.). SSRN, USA., pp: 131-148.

Chakravorti, S. and R. Roson, 2006. Platform competition in two-sided markets: The case of payment networks. Rev. Network Econ., 5: 118-142. DOI: $10.2202 / 1446-9022.1092$

Datamonitor, 2006. Contactless payments 2006. MarketResearch.com.

http://www.marketresearch.com/product/display.as p?productid $=1299163$

Distaso, W., P. Lupi and F.M. Manenti, 2006. Platform competition and broadband uptake: Theory and empirical evidence from the European Union. Inform. Econ. Policy, 18: 87-106. DOI: 10.1016/j.infoecopol.2005.07.002

Doganoglu, T. and J. Wright, 2005. Multihoming and compatibility. Int. J. Ind. Org., 24: 45-67. DOI: 10.1016/j.ijindorg.2005.07.004

European Central Bank, 2006. SEPA-single euro payment area for retail payments. ECB.

European Central Bank, 2007. Annual report 2007. ECB.

Evans, D.S., 2003. Some empirical aspects of multisided platform industries. Rev. Network Econ., 2: 191-209. DOI: 10.2202/1446-9022.1026

Farrell, J., 2006. Efficiency and competition between payment instruments. Rev. Network Econ., 5: 26-44. DOI: $10.2202 / 1446-9022.1087$

Mallat, N., 2007. Exploring consumer adoption of mobile payments-a qualitative study. J. Strat. Inform. Syst., 16: 413-432. DOI: 10.1016/j.jsis.2007.08.001

Milne, A., 2005. What is in it for us? Network effects and bank payment innovation. J. Bank. Finance, 30: 1613-1630. DOI: 10.1016/j.jbankfin.2005.09.006
Rochet, J.C. and J. Tirole, 2002. Cooperation among competitors: Some economics of payment card associations. RAND J. Econ., 33: 549-570. http://www.jstor.org/pss/3087474

Rochet, J.C. and J. Tirole, 2003. Platform competition in two-sided markets. J. Eur. Econ. Assoc., 1: 990-1029. http://www.jstor.org/pss/40005175

Rochet, J.C. and J. Tirole, 2004a. Defining two-sided markets. University of Paris and MIT. http://www.brousseau.info/semnum/pdf/2004-0301_tirole.pdf

Rochet, J.C. and J. Tirole, 2004b. Two-sided markets: An overview. Proceeding of the Economics of Two-Sided Markets Conference, Mar. 12-12, University of Toulouse, Mimeo, pp: 1-44. http://faculty.haas.berkeley.edu/hermalin/rochet_tir ole.pdf

Roson, R., 2005. Two-sided markets: A tentative survey. Rev. Network Econ., 4: 142-160. DOI: 10.2202/1446-9022.1070

Sadek, D.M., N.S. Zainal, M.S.I.M. Taher, A.F. Yahya and M.R. Shaharudin et al., 2010. Service quality perceptions between cooperative and Islamic Banks of Britain. Am. J. Econ. Bus. Admin., 2: 1-5. DOI: 10.3844/ajebasp.2010.1.5

Sarlak, M.A. and A.A. Hastiani, 2008. E-business barriers in Iran's free trade zones. J. Soc. Sci., 4: 329-333. http://www.scipub.org/fulltext/jss/jss44329-333.pdf

Sattar, J.A. and M.A. AL-Fayoumi, 2007. Anonymous and non-repudiation E-payment protocol. Am. J. Applied Sci., 4: 538-542. http://www.scipub.org/fulltext/ajas/ajas48538-542.pdf

Schiff, A., 2003. Open and closed systems of two-sided networks. Inform. Econ. Policy, 15: 425-442. DOI: 10.1016/S0167-6245(03)00006-4

Wright, J., 2003a. Optimal card payment systems. Eur. Econ. Rev., 47: 587-612. DOI: 10.1016/S00142921(02)00305-7

Wright, J., 2003b. Pricing in debit and credit card schemes. Econ. Lett., 80: 305-309. DOI: 10.1016/S0165-1765(03)00143-5

Zou, B., 2006. Vintage technology, optimal investment and technology adoption. Econ. Model., 23: 515-533. DOI: 10.1016/j.econmod.2006.02.005 